\title{
Lifestyle and Genetics in Obesity and type 2 Diabetes
}

\author{
Authors \\ T. Temelkova-Kurktschiev ${ }^{1,2}$, T. S. Stefanov ${ }^{1}$ \\ Affiliations \\ ${ }^{1}$ Medicobiological Unit, International Scientific Institute, National Sports Academy, Bulgaria \\ ${ }^{2}$ Robert Koch German Medical Center, Sofia, Bulgaria
}

Key words

- genetics

- lifestyle

- obesity

- type 2 diabetes

received 29.04.2011

first decision 17.07.2011

accepted 21.07.2011

\section{Bibliography}

DOI http://dx.doi.org/

10.1055/s-0031-1285832

Published online:

September 13, 2011

Exp Clin Endocrinol Diabetes

2012; 120: 1-6

J. A. Barth Verlag in

(c) Georg Thieme Verlag KG

Stuttgart · New York

ISSN 0947-7349

Correspondence

\section{Mr. T. S. Stefanov}

Medicobiological Unit International Scientific Institute National Sports Academy 1700 Studentski grad Sofia Bulgaria

Tel.: + 359/88/800 3607

tsvetan.stefanov@gmail.com

\section{Abstract}

$\nabla$

Obesity and type 2 diabetes mellitus are multifactorial health threats caused by a complex interplay between genetic predisposition and the environment with dramatically increasing worldwide prevalence. The role of heritability in their etiology is well recognized, however, the numerous attempts made in order certain genetic variants determining individual susceptibility to be identified have had limited success, until recently. At present the advancements in human genetics and the utilization of the genome-wide association approach have led to the identification of over 20 genetic loci associated with, respectively obesity and type 2 diabetes. Most of the genes identified to date, however, have modest effect on disease risk suggesting that both diseases are unlikely to develop without the individual being exposed to obesity- and/or type 2 diabetes-promoting environment. Indeed, unhealthy lifestyle, characterized

\section{Introduction \\ $\nabla$}

The prevalence of obesity and type 2 diabetes mellitus (T2DM) is dramatically increasing worldwide. For less than 2 decades the prevalence of obesity has more than doubled to exceed 470 million, representing the most common metabolic disease nowadays (International Obesity Taskforce, 2010). The rise in obesity prevalence is paralleled by a similar rapid increase in the prevalence of T2DM demonstrating the close interrelationship between these metabolic diseases (Wild et al., 2004).

Obesity and T2DM are multifactorial health threats caused by a complex interplay between genetic predisposition and the environment (Neel, 1999). The advancements in human genetics and the utilization of genome-wide association (GWA) approach have recently revealed by physical inactivity and food overconsumption is an unequivocally established risk factor for obesity and type 2 diabetes. Numerous epidemiological studies and randomized controlled trials, on the other hand, have demonstrated that lifestyle modification is effective in obesity and type 2 diabetes prevention. Furthermore, genelifestyle interaction studies suggest that genetic susceptibility to obesity and type 2 diabetes may be partially or totally kept under control by healthy lifestyle or lifestyle modification and that lifestyle determines whether an individual is likely to develop the disease. Inherited factors, however, seem to influence individual response to a lifestyle intervention program and even the motivation for lifestyle change. Personalized interventions according to genotype may be, therefore, considered in the future. By then lifestyle modification targeting dietary change and increased physical activity may be recommended for successful obesity and type 2 diabetes prevention irrespectively of genetic susceptibility.

valuable insights into the interactions between genetic predisposition and lifestyle factors, namely physical activity (PA) and food consumption. This current progress may have essential contribution to our understanding of the pathophysiology of both diseases, as well as, to the development and implementation of future treatment and prevention strategies. It is, therefore, the aim of the present review to summarize the available literature on the effect of the interactions between lifestyle and genetics on obesity and T2DM.

\section{Genetics of Obesity and Type 2 Diabetes Mellitus \\ $\nabla$}

The role of heritability in the development of obesity and T2DM is well recognized. A good 
example in this respect is the existence of severe monogenic forms of both disorders such as the congenital leptin deficiency (Montague et al., 1997), the melanocortin-4 receptor deficiency (Farooqi et al., 2003), and the maturity onset diabetes of the young (MODY) (Vaxillaire and Froguel, 2006). The strong impact of inherited factors on obesity and T2DM has also been confirmed in a large number of family, twin and adoption studies. Studies in twins have demonstrated that $50-70 \%$ in the body mass index (BMI) variance may be explained by genetics (Allison et al., 1996), and T2DM concordance was reported ranging from $17-37 \%$ in dizygotic to $50-70 \%$ in monozygotic twins (Kaprio et al., 1992; Medici et al., 1999; Poulsen et al., 1999). In addition, family and adoption studies have reported heritability ranging from $20-60 \%$ for obesity (Rice et al., 1999; Stunkard et al., 1986) and $30-70 \%$ for T2DM (Meigs et al., 2000).

During the past 15 years numerous attempts have been made to identify certain genetic variants determining susceptibility to obesity and T2DM. Until recently candidate gene and genomewide linkage studies have been the main genetic epidemiological approaches. Progress has, however, been slow and success limited with few reproducible results (Vimaleswaran and Loos, 2010). Utilization of the GWA approach and the progress made through the International HapMap project and the Human Genome Project has substantially improved the knowledge about obesity and T2DM genetics (Rankinen et al., 2006). At present, as a result of this technological advancement over 20 loci for respectively obesity and T2DM have been convincingly confirmed in various populations (Herder and Roden, 2010; Vimaleswaran and Loos, 2010).

Extensive description of the genetic variants influencing individual susceptibility to obesity and T2DM is beyond the scope of the current paper (for a detailed review on the topic, please refer to (Herder and Roden, 2010; Vimaleswaran and Loos, 2010). We are rather aiming at demonstrating the effect of gene-lifestyle interactions on the development of diabesity. Most of the genes identified to date have modest effect on disease risk and both diseases are unlikely to develop without the individual being exposed to obesity- and/or type 2 diabetes-promoting environment. Therefore, in the next section the importance of lifestyle in obesity and T2DM will be discussed.

\section{Lifestyle in Obesity and Type 2 Diabetes Mellitus $\nabla$}

Unhealthy lifestyle, characterized by physical inactivity and food overconsumption is an unequivocally established risk factor for obesity and type 2 diabetes. Increased PA and energy restriction, on the other hand, are associated with lower incidence of obesity and T2DM in numerous epidemiological studies.

\section{Lessons from epidemiological studies}

Findings from cross-sectional and prospective studies suggest that food overconsumption and a predominantly sedentary lifestyle may cause obesity and T2DM, while adoption of a healthier lifestyle may prevent them. It has been demonstrated that lack of non-sedentary activities, the time spent watching television, and western dietary pattern can substantially increase the odds of becoming obese and of developing T2DM (Ching et al., 1996; Martinez-Gonzalez et al., 1999; Schulze et al., 2006; van Dam et al., 2002). At the same time a healthier lifestyle comprising higher levels of PA and prudent food consumption have been found to significantly reduce the risk (Coakley et al., 1998; Kriska et al., 2003; Meisinger et al., 2005; Schulze et al., 2006; van Dam et al., 2002). In a recent paper we reported that low levels of leisure time and sport PA, as well as, binge eating behavior are associated with increased BMI and higher T2DM prevalence also among the urban population of Sofia, Bulgaria (Stefanov et al., 2011).

Based on data analyses from the Nurses' Health Study Hu et al. (2003a) concluded that around $30 \%$ of the new cases of obesity and $43 \%$ of T2DM could be prevented by adoption of a relatively active lifestyle. Indeed, activities of even moderate intensity (e.g., brisk walking) have been found to significantly reduce the risk of obesity and diabetes (Hu et al., 1999; Hu et al., 2003b; Mekary et al., 2009). Remarkably, the effect of PA on diabetes incidence has been observed independently of BMI demonstrating that regular engagement in activities of moderate to high intensity may be beneficial not only for high-risk obese individuals, but also for low-risk lean individuals (Kriska et al., 2003; Meisinger et al., 2005; Schulze et al., 2006). Furthermore, healthier lifestyle has been shown to be associated with decreased incidence of obesity- and T2DM-related complications such as hypertension and cardiovascular disease (Manson et al., 2002; Stampfer et al., 2000).

\section{Evidence from randomized controlled trails}

The efficacy of lifestyle changes in obesity and T2DM prevention has been established in numerous randomized controlled trails (RCTs). Several of them may, however, be considered of major importance due to their large sample sizes (i.e., 458-3234 individuals) and long-term duration (i.e., 3-6 years). The Chinese Da Qing diabetes prevention study was the first to investigate the effect of 6-year lifestyle change on body weight and diabetes incidence in individuals with impaired glucose tolerance (IGT) (Pan et al., 1997). Pan and co-workers (1997) reported $42 \%$ reduction in diabetes incidence, although no significant difference in body weight was present. Similar results were found in the Finnish Diabetes Prevention Study (DPS) and the US Diabetes Prevention Program (DPP). DPS and DPP independently reported reduction in diabetes incidence of $58 \%$ accompanied by significant reduction in body weight (5-7\%) as a result of the lifestyle modification (Knowler et al., 2002; Tuomilehto et al., 2001). These findings were also confirmed in Japanese and Indian populations, reporting $67.4 \%$ and $28.5 \%$ reduction in diabetes incidence, respectively (Kosaka et al., 2005; Ramachandran et al., 2006). All the above mentioned findings have been also reproduced in several smaller RCTs (Eriksson and Lindgarde, 1991; Penn et al., 2009; Wing et al., 1998). Remarkably in the Finnish DPS success of achieving study goals was inversely associated with diabetes incidence and none of the subjects who reached 4 of 5 study goals developed T2DM (Tuomilehto et al., 2001).

Very recently the interventions that proved efficient in clinical research were successfully translated in a real-world situation (Sanake et al., 2011). Sanake et al. (2011) reported significant reduction in body weight and diabetes incidence at 1 , as well as, at 3 years during a lifestyle modification program carried out in a primary healthcare setting among subjects with IGT.

All large-scale interventions have been successful in preventing T2DM during the active intervention period. Remarkably when the effectiveness of the lifestyle modification programs was assessed on the long-term after discontinuation of the intervention, diabetes risk still remained substantially reduced. In the Finnish DPS, for instance, at extended follow-up 3 years after the 4-year intervention period a substantial reduction in body weight and T2DM incidence was still present (Lindstrom et al., 
2006). The follow-up period of the Da Qing study was even longer - 14 year. Interestingly diabetes risk at that point was reduced to even greater extent in comparison to the 6-year active intervention ( $\mathrm{Li}$ et al., 2008). In addition to these observations, 7 years after the intervention was discontinued in the U.S. DPP body weight and T2DM incidence still remained significantly lower in the lifestyle intervention group when compared to the control group (Knowler et al., 2009).

As already pointed out in several of the T2DM prevention studies the reduction in diabetes risk has been paralleled by substantial weight loss and weight reduction has been considered to have major importance for diabetes prevention (Knowler et al., 2002; Kosaka et al., 2005; Lindstrom et al., 2003; Tuomilehto et al., 2001). In some studies although no or just minor weight loss was achieved, diabetes incidence was also reduced (Pan et al., 1997; Ramachandran et al., 2006). In addition, on the long term weight was partially or totally regained in all of the studies (Knowler et al., 2009; Li et al., 2008; Lindstrom et al., 2006; Lindstrom et al., 2003). Despite this regain T2DM risk remained low or decreased further, thus the effect of lifestyle is unlikely to be solely due to body weight reduction. In support of this notion Pan et al. (1997) reported comparable decrease in T2DM incidence in the intervention group of Da Qing among overweight and lean individuals.

Furthermore, significant improvement in various metabolic parameters has been observed irrespectively of the degree of weight loss (Eriksson and Lindgarde, 1991; Knowler et al., 2002; Kosaka et al., 2005; Pan et al., 1997; Ramachandran et al., 2006; Tuomilehto et al., 2001; Wing et al., 1998). This reduction remained lower even when weight was partially or totally regained in some of the studies (Pan et al., 1997; Wing et al., 1998). Hence, lifestyle modification seems to have an effect on T2DM not only through reduction in body weight, but also through improvement in insulin sensitivity, blood glucose control and lipid profile.

Whereas there is convincing evidence that lifestyle changes can prevent T2DM in randomized controlled studies, so far little is known whether a lifestyle intervention could also modify cardiovascular morbidity and mortality. The 20-year follow-up results from the Chinese Da Qing diabetes prevention study showed a non-significant $17 \%$ reduction in cardiovascular mortality in the combined (diet and/or PA) intervention group vs. controls (Li et al., 2008). Similarly, lifestyle intervention in the Finnish DPS was not found to reduce significantly cardiovascular mortality during the first 10 years of follow-up (Uusitupa et al., 2009). However, this study was not initially designed to examine the effect of lifestyle intervention on total mortality or cardiovascular morbidity, and therefore the statistical power may not have been sufficient to detect small differences in cardiovascular events between the 2 groups. Besides, a longer follow-up period might be needed to answer this question. In the Malmö Preventive trial with a 12-year follow-up of men with IGT total and cardiovascular mortality were lower among participants in the lifestyle intervention group, however, these results should be considered with caution due to the non-randomized design of the study (Eriksson and Lindgarde, 1998). Recent findings of bariatric surgery treatment of very obese subjects showed that weight loss indeed may reduce not only T2DM risk but also total mortality (Sjöström et al., 2007). Further investigations are needed to clarify whether prevention of T2DM by lifestyle modification is associated with cardiovascular disease prevention; until then decisions have to be made on the basis of the best available information.
In conclusion, evidence from epidemiological studies and RCTs demonstrate that lifestyle modification comprising higher levels of PA and prudent food consumption may be effective in obesity and T2DM prevention. The positive effect of lifestyle on body weight seems somewhat transient, whereas the effect on T2DM is sustained for longer periods. Furthermore, lifestyle modification appears to have an effect on diabetes risk independently of body weight and even of weight loss.

\section{Lifestyle and Genetics in Obesity and Type 2 Diabetes \\ $\nabla$}

Recent advancement in human genetics has led to the identification of a relatively big number of obesity- and T2DM-associated loci. Their contribution to disease risk has, however, been shown to be small and their predictive value low, suggesting that lifestyle plays crucial role in obesity and T2DM development (Vimaleswaran and Loos, 2010). Indeed, studies investigating the gene-lifestyle interactions in obesity and T2DM have suggested that the biological effect of genetic predisposition may be partially or totally abolished by healthy lifestyle or lifestyle modification and vice versa.

Epidemiological studies have reported that the negative effect of several obesity- and T2DM-associated genes may be attenuated in individuals with higher PA levels or healthy lifestyle, whereas low PA and western dietary pattern have been found to accentuate it. (Ahmad et al., 2011; Andreasen et al., 2008; Brito et al., 2009; Nelson et al., 2007; Qi et al., 2009; Rampersaud et al., 2008; Ruchat et al., 2010; Ruiz et al., ; Vimaleswaran et al., 2009). In addition, physical activity, dietary and combined lifestyle interventions have been found to induce significant decreases in body weight and other anthropometric traits, thus abolishing obesity risk among carriers of risk alleles in 2 of the genes most strongly associated with obesity - FTO and MC4R (Franks et al., 2008; Haupt et al., 2009a; Haupt et al., 2008; Lappalainen et al., 2009; Mitchell et al., 2010; Razquin et al., 2010). With respect to T2DM results from several large-scale studies have provided strong evidence for amelioration of metabolic traits and attenuation of diabetes risk among TCF7L2 risk allele carriers by diet and exercise (Bo et al., 2009; Florez et al., 2006; Haupt et al., 2010; Wang et al., 2007). The minor allele of PPARgamma gene has also been associated with substantially increased risk for T2DM and atherosclerosis (Deeb et al., 1998; Temelkova-Kurktschiev et al., 2004). Lifestyle modification has, however, been suggested to attenuate its negative effect on metabolic profile, body weight, and diabetes risk (Franks et al., 2007; Kilpelainen et al., 2008; Lindi et al., 2002; Ruchat et al., 2010) (○ Table 1). The notion that lifestyle modification can eliminate the increased risk for development of T2DM in subjects with genetic susceptibility is also supported by findings of Barwell et al. (2008) who reported that women with family history of T2DM experience greater improvement in insulin sensitivity following an exercise intervention than women with no family history.

Although lifestyle modification has been found efficient in obesity and T2DM prevention even among genetically susceptible individuals, considerable heterogeneity in intervention responses has been observed. Genetic influences have been suggested to contribute to this heterogeneity. Risk allele carriers in several obesity- and T2DM-associated genes, for instance, have been found to experience suppressed weight reduction and improvement in various metabolic parameters in response to exercise or combined lifestyle interventions (Franks et al., 2007; Haupt et al., 
Table 1 Gene-lifestyle interaction studies supporting the protective role of diet, exercise or combined lifestyle interventions in individuals genetically susceptible to obesity and type 2 diabetes.

\begin{tabular}{|c|c|c|c|c|}
\hline Study & Population & Intervention & $\begin{array}{l}\text { Polymorphism } \\
\text { investigated }\end{array}$ & Findings \\
\hline Franks et al., 2008 & $\begin{array}{l}908 \text { individuals with IGT or } \\
\text { impaired fasting glucose }\end{array}$ & $\begin{array}{l}\text { Combined lifestyle intervention } \\
-24 \text { weeks of intensive coun- } \\
\text { seling and 3-year follow-up }\end{array}$ & $\begin{array}{l}\text { FTO } \\
\text { SNP: rs9939609 }\end{array}$ & $\begin{array}{l}\text { Subcutaneous adipose tissue } \\
\text { decreased irrespectively of genotype }\end{array}$ \\
\hline $\begin{array}{l}\text { Lappalainen et al., } \\
2009\end{array}$ & $\begin{array}{l}502 \text { European individuals } \\
\text { with overweight and IGT, } \\
\text { aged } 40-65 \text { years }\end{array}$ & $\begin{array}{l}\text { Combined lifestyle intervention } \\
-1 \text { year of intensive counseling } \\
\text { and 3-year follow-up }\end{array}$ & $\begin{array}{l}\text { FTO } \\
\text { SNP: rs9939609 }\end{array}$ & $\begin{array}{l}\text { No association between the variant } \\
\text { and the magnitude of weight } \\
\text { reduction }\end{array}$ \\
\hline Haupt et al., 2008 & $\begin{array}{l}204 \text { European individuals } \\
\text { with overweight, IGT family } \\
\text { history of T2DM or history } \\
\text { of gestational diabetes }\end{array}$ & $\begin{array}{l}\text { 9-month combined lifestyle } \\
\text { intervention }\end{array}$ & $\begin{array}{l}\text { FTO } \\
\text { SNP: rs } 8050136\end{array}$ & $\begin{array}{l}\text { The FTO variant did not affect } \\
\text { reduction in body weight, total } \\
\text { fat, subcutaneous fat, visceral, and } \\
\text { nonvisceral fat }\end{array}$ \\
\hline Mitchell et al., 2010 & $\begin{array}{l}234 \text { white, overweight } \\
\text { postmenopausal women, } \\
\text { aged } 45-75 \text { years }\end{array}$ & $\begin{array}{l}\text { 6-month moderate intensity } \\
\text { exercise intervention }\end{array}$ & $\begin{array}{l}\text { FTO } \\
\text { SNP: rs } 8050136\end{array}$ & $\begin{array}{l}\text { Comparable weight loss occurred } \\
\text { among genotypes }\end{array}$ \\
\hline Razquin et al., 2010 & $\begin{array}{l}776 \text { subjects at risk of CVD, } \\
\text { aged } 55-80 \text { years }\end{array}$ & 3-year dietary intervention & $\begin{array}{l}\text { FTO } \\
\text { SNP: rs9939609 }\end{array}$ & $\begin{array}{l}\text { Risk allele carriers had lower weight } \\
\text { gain compared to noncarriers }\end{array}$ \\
\hline Haupt et al., 2009a & $\begin{array}{l}242 \text { European individuals } \\
\text { with overweight, IGT, family } \\
\text { history of T2DM or history } \\
\text { of gestational diabetes }\end{array}$ & $\begin{array}{l}\text { 9-month combined lifestyle } \\
\text { intervention }\end{array}$ & $\begin{array}{l}\text { MC4R } \\
\text { SNP: rs17782313 }\end{array}$ & $\begin{array}{l}\text { The FTO variant did not affect } \\
\text { reduction in body weight, total fat, } \\
\text { visceral, and nonvisceral fat }\end{array}$ \\
\hline Bo et al., 2009 & $\begin{array}{l}335 \text { nondiabetic, dysmeta- } \\
\text { bolic patients }\end{array}$ & 1-year lifestyle intervention & $\begin{array}{l}\text { TCF7L2 } \\
\text { SNP: rs7903146 }\end{array}$ & $\begin{array}{l}\text { Lifestyle modification improved } \\
\text { the metabolic pattern in all genetic } \\
\text { subgroups }\end{array}$ \\
\hline Florez et al., 2006 & $\begin{array}{l}3548 \text { individuals with IGT } \\
\text { or impaired fasting glucose }\end{array}$ & $\begin{array}{l}\text { Combined lifestyle intervention } \\
-24 \text { weeks of intensive coun- } \\
\text { seling and 3-year follow-up }\end{array}$ & $\begin{array}{l}\text { TCF7L2 } \\
\text { SNPs: rs12255372 } \\
\text { and rs7903146 }\end{array}$ & $\begin{array}{l}\text { The effect of the risk alleles in } \\
\text { TCF7L2 on the progression to T2DM } \\
\text { was abolished by lifestyle }\end{array}$ \\
\hline Wang et al., 2007 & $\begin{array}{l}507 \text { European individuals } \\
\text { with overweight and IGT, } \\
\text { aged } 40-65 \text { years }\end{array}$ & $\begin{array}{l}\text { Combined lifestyle intervention } \\
-1 \text { year of intensive counseling } \\
\text { and 3-year follow-up }\end{array}$ & $\begin{array}{l}\text { TCF7L2 } \\
\text { SNPs: rs12255372 } \\
\text { and rs7903146 }\end{array}$ & $\begin{array}{l}\text { Genetic susceptibility to T2DM was } \\
\text { abolished by lifestyle }\end{array}$ \\
\hline Haupt et al., 2010 & $\begin{array}{l}309 \text { nondiabetic Ger- } \\
\text { man Caucasian subject at } \\
\text { increased risk for T2DM }\end{array}$ & $\begin{array}{l}\text { 9-month combined lifestyle } \\
\text { intervention }\end{array}$ & $\begin{array}{l}\text { TCF7L2 } \\
\text { SNP: rs7903146 }\end{array}$ & $\begin{array}{l}\text { "At risk" genotype was not } \\
\text { associated with changes in fasting or } \\
120 \text {-min glucose, insulin sensitivity } \\
\text { or insulin secretion }\end{array}$ \\
\hline Lindi et al., 2002 & $\begin{array}{l}490 \text { European individuals } \\
\text { with overweight and IGT, } \\
\text { aged } 40-65 \text { years }\end{array}$ & $\begin{array}{l}\text { Combined lifestyle intervention } \\
-1 \text { year of intensive counseling } \\
\text { and 3-year follow-up }\end{array}$ & $\begin{array}{l}\text { PPARgamma } \\
\text { SNP: Pro12Ala }\end{array}$ & $\begin{array}{l}\text { Lifestyle modification was associated } \\
\text { with reduced T2DM and decreased } \\
\text { body weight irrespectively of } \\
\text { genotype }\end{array}$ \\
\hline Franks et al., 2007 & $\begin{array}{l}3234 \text { individuals with IGT or } \\
\text { impaired fasting glucose }\end{array}$ & $\begin{array}{l}\text { Combined lifestyle intervention } \\
-24 \text { weeks of intensive coun- } \\
\text { seling and 3-year follow-up }\end{array}$ & $\begin{array}{l}\text { PPARgamma } \\
\text { SNP: Pro12Ala }\end{array}$ & $\begin{array}{l}\text { In the lifestyle arm reduction in body } \\
\text { weight and subcutaneous adipose } \\
\text { tissue occurred irrespectively of } \\
\text { genotype }\end{array}$ \\
\hline Kilpelainen et al., 2008 & $\begin{array}{l}479 \text { European individuals } \\
\text { with overweight and IGT, } \\
\text { aged } 40-65 \text { years }\end{array}$ & $\begin{array}{l}\text { Combined lifestyle intervention } \\
-1 \text { year of intensive counseling } \\
\text { and 3-year follow-up }\end{array}$ & $\begin{array}{l}\text { PPARgamma } \\
\text { SNPs: rs } 17036314 \text {, } \\
\text { rs1801282, and } \\
\text { rs } 1152003\end{array}$ & $\begin{array}{l}\text { Increased PA seems to decrease the } \\
\text { negative effect of the risk alleles } \\
\text { in rs } 17036314 \text { and rs } 1801282 \text {, } \\
\text { whereas combined lifestyle change } \\
\text { abolished rs } 1152003 \text {-associated risk }\end{array}$ \\
\hline Ruchat et al., 2010 & $\begin{array}{l}481 \text { sedentary, non-diabetic } \\
\text { white individuals }\end{array}$ & $\begin{array}{l}\text { 20-week endurance training } \\
\text { program }\end{array}$ & $\begin{array}{l}\text { PPARgamma } \\
\text { SNP: rs1801282 }\end{array}$ & $\begin{array}{l}\text { Improvements in metabolic profile } \\
\text { occurred across genotypes }\end{array}$ \\
\hline
\end{tabular}

SNP, single nucleotide polymorphism

2010; Lindi et al., 2002; Reinehr et al., 2008; Ruchat et al., 2010; Weyrich et al., 2008). Thus, genetic variations in PPARD and PPARGC1A were shown to determine mitochondrial function and change in aerobic physical fitness and insulin sensitivity during lifestyle intervention (Stefan et al., 2007) and individuals carrying the minor alleles of the PPARD SNPs rs1053049, rs6902123, and rs2267668 were found to benefit from exercise and weight loss to a lesser extent (Thamer et al., 2008). Besides, the NDUFB6 gene polymorphism, known to regulate mitochondrial function, was suggested to contribute to the response of ATP synthesis to exercise training and the A allele carriers of the NDUFB6 SNP, rs540467, were reported to show a variation in the response to exercise (Kacerovsky-Bielesz et al., 2009).

Furthermore, it has been suggested that genetic factors may be involved in determination of individual PA level and energy intake (Leibel, 2008; Teran-Garcia et al., 2008). With this respect Stubbe et al. (2006) based on analysis from a collaborative study involving 85198 twins suggested that heritability of exercise participation may range from $48 \%$ to $71 \%$. Family studies have also reported heritability of PA ranging from 19\% to 46\% (Cai et al., 2006; Simonen et al., 2002). In addition obesity-related genetic polymorphisms have been associated with increased energy intake and 
preference for foods of high energy density (Haupt et al., 2009b; Speakman et al., 2008; Timpson et al., 2008).

In summary, healthy lifestyle or lifestyle modification may keep genetic predisposition to obesity and T2DM under control. Genetics has, however, been suggested to influence the outcome of a lifestyle intervention or even to determine individual PA level, food intake, and motivation for lifestyle change.

\section{Conclusions}

\section{$\nabla$}

Obesity and T2DM are clearly the results of a complex interplay between inherited factors and the environment. Recent advancements made through the GWA approach have substantially contributed to our understanding of obesity and T2DM genetics, however, most of the loci identified to date have modest effect on disease risk. Hence, lifestyle factors, namely physical inactivity and food overconsumption seem to have major importance for the development of both diseases.

Healthy lifestyle and lifestyle modification, on the other hand, appear to be the most efficient tools for obesity and T2DM prevention. In addition, gene-lifestyle interaction studies suggest that lifestyle determines whether an individual is likely to develop the disease and that genetic susceptibility may be partially or totally kept under control by lifestyle modification. Since genetics seems to influence individual response to a lifestyle intervention and even the motivation for lifestyle change, personalized interventions according to genotype may be considered in the future. By then lifestyle modification targeting dietary change and increased physical activity may be recommended for successful obesity and T2DM prevention irrespectively of genetic susceptibility.

\section{Conflict of Interest: None.}

\section{References}

1 Ahmad T, Lee IM, Pare G et al. Lifestyle Interaction With Fat Mass and Obesity-Associated (FTO) Genotype and Risk of Obesity in Apparently Healthy U.S. Women. Diabetes Care 2011; 34: 675-680

2 Allison DB, Kaprio J, Korkeila $M$ et al. The heritability of body mass index among an international sample of monozygotic twins reared apart. Int J Obes Relat Metab Disord 1996; 20: 501-506

3 Andreasen $\mathrm{CH}$, Stender-Petersen KL, Mogensen MS et al. Low physical activity accentuates the effect of the FTO rs9939609 polymorphism on body fat accumulation. Diabetes 2008; 57: 95-101

4 Barwell ND, Malkova D, Moran CN et al. Exercise training has greater effects on insulin sensitivity in daughters of patients with type 2 diabetes than in women with no family history of diabetes. Diabetologia 2008; 51: 1912-1919

5 Bo S, Gambino R, Ciccone G et al. Effects of TCF7L2 polymorphisms on glucose values after a lifestyle intervention. Am J Clin Nutr 2009; 90: $1502-1508$

6 Brito EC, Lyssenko V, Renstrom $F$ et al. Previously associated type 2 diabetes variants may interact with physical activity to modify the risk of impaired glucose regulation and type 2 diabetes: a study of 16003 Swedish adults. Diabetes 2009; 58: 1411-1418

7 Cai G, Cole SA, Butte $N$ et al. A quantitative trait locus on chromosome $18 \mathrm{q}$ for physical activity and dietary intake in Hispanic children. Obesity (Silver Spring) 2006; 14: 1596-1604

8 Ching PL, Willett WC, Rimm EB et al. Activity level and risk of overweight in male health professionals. Am J Public Health 1996; 86: 25-30

9 Coakley EH, Rimm EB, Colditz G et al. Predictors of weight change in men: results from the Health Professionals Follow-up Study. Int J Obes Relat Metab Disord 1998; 22: 89-96

10 Deeb SS, Fajas L, Nemoto $M$ et al. Pro12Ala substitution in PPARgamma2 associated with decreased receptor activity, lower body mass index and improved insulin sensitivity. Nat Genet 1998; 20: 284-287
11 Eriksson $K F$, Lindgarde F. Prevention of type 2 (non-insulin-dependent) diabetes mellitus by diet and physical exercise. The 6-year Malmo feasibility study. Diabetologia 1991; 34: 891-898

12 Eriksson KF, Lindgarde $F$. No excess 12-year mortality in men with impaired glucose tolerance who participated in the Malmo Preventive Trial with diet and exercise. Diabetologia 1998; 41: 1010-1016

13 Farooqi IS, Keogh JM, Yeo GS et al. Clinical spectrum of obesity and mutations in the melanocortin 4 receptor gene. N Engl J Med 2003; 348: 1085-1095

14 Florez JC, Jablonski KA, Bayley $N$ et al. TCF7L2 polymorphisms and progression to diabetes in the Diabetes Prevention Program. N Engl J Med 2006; 355: 241-250

15 Franks PW, Jablonski KA, Delahanty L et al. The Pro12Ala variant at the peroxisome proliferator-activated receptor gamma gene and change in obesity-related traits in the Diabetes Prevention Program. Diabetologia 2007; 50: 2451-2460

16 Franks PW, Jablonski KA, Delahanty LM et al. Assessing gene-treatment interactions at the FTO and INSIG2 loci on obesity-related traits in the Diabetes Prevention Program. Diabetologia 2008; 51: 2214-2223

17 Haupt A, Thamer C, Heni $M$ et al. Gene variants of TCF7L2 influence weight loss and body composition during lifestyle intervention in a population at risk for type 2 diabetes. Diabetes 2010; 59: 747-750

18 Haupt A, Thamer C, Heni $M$ et al. Impact of variation near MC4R on whole-body fat distribution, liver fat, and weight loss. Obesity (Silver Spring) 2009; 17: 1942-1945

19 Haupt A, Thamer C, Machann J et al. Impact of variation in the FTO gene on whole body fat distribution, ectopic fat, and weight loss. Obesity (Silver Spring) 2008; 16: 1969-1972

20 Haupt A, Thamer C, Staiger H et al. Variation in the FTO gene influences food intake but not energy expenditure. Exp Clin Endocrinol Diabetes 2009; 117: 194-197

21 Herder C, Roden $M$. Genetics of type 2 diabetes: pathophysiologic and clinical relevance. Eur J Clin Invest 2010; 41: 679-692

$22 \mathrm{Hu}$ FB, Li TY, Colditz GA et al. Television watching and other sedentary behaviors in relation to risk of obesity and type 2 diabetes mellitus in women. Jama 2003; 289: 1785-1791

$23 \mathrm{Hu} F B$, Sigal RJ, Rich-Edwards JW et al. Walking compared with vigorous physical activity and risk of type 2 diabetes in women: a prospective study. Jama 1999; 282: 1433-1439

$24 \mathrm{Hu}$ G, Qiao Q Silventoinen Ket al. Occupational, commuting, and leisuretime physical activity in relation to risk for Type 2 diabetes in middleaged Finnish men and women. Diabetologia 2003; 46: 322-329

25 International Obesity Taskforce. Obesity the global epidemic. Available from http://www.iaso.org/iotf/obesity/obesitytheglobalepidemic/ (cited 23 March 2011).

26 Kacerovsky-Bielesz G, Chmelik M, Ling C et al. Short-term exercise training does not stimulate skeletal muscle ATP synthesis in relatives of humans with type 2 diabetes. Diabetes 2009; 58: 1333-1341

27 Kaprio J, Tuomilehto J, Koskenvuo $M$ et al. Concordance for type 1 (insulin-dependent) and type 2 (non-insulin-dependent) diabetes mellitus in a population-based cohort of twins in Finland. Diabetologia 1992; 35: 1060-1067

28 Kilpelainen TO, Lakka TA, Laaksonen DE et al. SNPs in PPARG associate with type 2 diabetes and interact with physical activity. Med Sci Sports Exerc 2008; 40: 25-33

29 Knowler WC, Barrett-Connor E, Fowler SE et al. Reduction in the incidence of type 2 diabetes with lifestyle intervention or metformin. N Engl J Med 2002; 346: 393-403

30 Knowler WC, Fowler SE, Hamman RF et al. 10-year follow-up of diabetes incidence and weight loss in the Diabetes Prevention Program Outcomes Study. Lancet 2009; 374: 1677-1686

31 Kosaka K, Noda M, Kuzuya T. Prevention of type 2 diabetes by lifestyle intervention: a Japanese trial in IGT males. Diabetes Res Clin Pract 2005; 67: 152-162

32 Kriska AM, Saremi A, Hanson RL et al. Physical activity, obesity, and the incidence of type 2 diabetes in a high-risk population. Am J Epidemiol 2003; 158: 669-675

33 Lappalainen TJ, Tolppanen AM, Kolehmainen $M$ et al. The common variant in the FTO gene did not modify the effect of lifestyle changes on body weight: the Finnish Diabetes Prevention Study. Obesity (Silver Spring) 2009; 17: 832-836

34 Leibel RL. Energy in, energy out, and the effects of obesity-related genes. N Engl J Med 2008; 359: 2603-2604

$35 \mathrm{Li} \mathrm{G}$, Zhang P, Wang J et al. The long-term effect of lifestyle interventions to prevent diabetes in the China Da Qing Diabetes Prevention Study: a 20-year follow-up study. Lancet 2008; 371: 1783-1789 
36 Lindi VI, Uusitupa MI, Lindstrom J et al. Association of the Pro12Ala polymorphism in the PPAR-gamma2 gene with 3-year incidence of type 2 diabetes and body weight change in the Finnish Diabetes Prevention Study. Diabetes 2002; 51: 2581-2586

37 Lindstrom J, Ilanne-Parikka P, Peltonen $M$ et al. Sustained reduction in the incidence of type 2 diabetes by lifestyle intervention: follow-up of the Finnish Diabetes Prevention Study. Lancet 2006; 368: 1673-1679

38 Lindstrom J, Louheranta A, Mannelin $M$ et al. The Finnish Diabetes Prevention Study (DPS): Lifestyle intervention and 3-year results on diet and physical activity. Diabetes Care 2003; 26: 3230-3236

39 Manson JE, Greenland P, LaCroix AZ et al. Walking compared with vigorous exercise for the prevention of cardiovascular events in women. N Engl J Med 2002; 347: 716-725

40 Martinez-Gonzalez MA, Martinez JA, Hu FB et al. Physical inactivity, sedentary lifestyle and obesity in the European Union. Int J Obes Relat Metab Disord 1999; 23: 1192-1201

41 Medici F, Hawa M, Ianari A et al. Concordance rate for type II diabetes mellitus in monozygotic twins: actuarial analysis. Diabetologia 1999; 42: $146-150$

42 Meigs JB, Cupples LA, Wilson PW. Parental transmission of type 2 diabetes: the Framingham Offspring Study. Diabetes 2000; 49: 2201-2207

43 Meisinger $C$, Lowel $H$, Thorand $B$ et al. Leisure time physical activity and the risk of type 2 diabetes in men and women from the general population. The MONICA/KORA Augsburg Cohort Study. Diabetologia 2005; 48: 27-34

44 Mekary RA, Feskanich D, Malspeis S et al. Physical activity patterns and prevention of weight gain in premenopausal women. Int J Obes (Lond) 2009; 33: 1039-1047

45 Mitchell JA, Church TS, Rankinen T et al. FTO genotype and the weight loss benefits of moderate intensity exercise. Obesity (Silver Spring) 2010; 18: 641-643

46 Montague CT, Farooqi IS, Whitehead JP et al. Congenital leptin deficiency is associated with severe early-onset obesity in humans. Nature 1997; 387: 903-908

47 Neel JV. Diabetes mellitus: a "thrifty" genotype rendered detrimental by "progress"? 1962. Bull World Health Organ 1999; 77: 694-703 discussion 692-693

48 Nelson TL, Fingerlin TE, Moss LK et al. Association of the peroxisome proliferator-activated receptor gamma gene with type 2 diabetes mellitus varies by physical activity among non-Hispanic whites from Colorado. Metabolism 2007; 56: 388-393

49 Pan XR, Li GW, Hu YH et al. Effects of diet and exercise in preventing NIDDM in people with impaired glucose tolerance. The Da Qing IGT and Diabetes Study. Diabetes Care 1997; 20: 537-544

50 Penn L, White M, Oldroyd J et al. Prevention of type 2 diabetes in adults with impaired glucose tolerance: the European Diabetes Prevention RCT in Newcastle upon Tyne, UK. BMC Public Health 2009; 9: 342

51 Poulsen P, Kyvik KO, Vaag A et al. Heritability of type II (non-insulindependent) diabetes mellitus and abnormal glucose tolerance - a population-based twin study. Diabetologia 1999; 42: 139-145

52 Qi L, Cornelis MC, Zhang C et al. Genetic predisposition, Western dietary pattern, and the risk of type 2 diabetes in men. Am J Clin Nutr 2009; 89: 1453-1458

53 Ramachandran A, Snehalatha C, Mary S et al. The Indian Diabetes Prevention Programme shows that lifestyle modification and metformin prevent type 2 diabetes in Asian Indian subjects with impaired glucose tolerance (IDPP-1). Diabetologia 2006; 49: 289-297

54 Rampersaud E, Mitchell BD, Pollin TI et al. Physical activity and the association of common FTO gene variants with body mass index and obesity. Arch Intern Med 2008; 168: 1791-1797

55 Rankinen T, Zuberi A, Chagnon YC et al. The human obesity gene map: the 2005 update. Obesity (Silver Spring) 2006; 14: 529-644

56 Razquin C, Martinez JA, Martinez-Gonzalez MA et al. A 3-year intervention with a Mediterranean diet modified the association between the rs9939609 gene variant in FTO and body weight changes. Int J Obes (Lond) 2010; 34: 266-272

57 Reinehr T, Friedel S, Mueller TD et al. Evidence for an influence of TCF7L2 polymorphism rs7903146 on insulin resistance and sensitivity indices in overweight children and adolescents during a lifestyle intervention. Int J Obes (Lond) 2008; 32: 1521-1524

58 Rice T, Perusse L, Bouchard C et al. Familial aggregation of body mass index and subcutaneous fat measures in the longitudinal Quebec family study. Genet Epidemiol 1999; 16: 316-334

59 Ruchat SM, Rankinen T, Weisnagel SJ et al. Improvements in glucose homeostasis in response to regular exercise are influenced by the PPARG Pro12Ala variant: results from the HERITAGE Family Study. Diabetologia 2010; 53: 679-689
60 Ruiz JR, Labayen I, Ortega FB et al. Attenuation of the effect of the FTO rs9939609 polymorphism on total and central body fat by physical activity in adolescents: the HELENA study. Arch Pediatr Adolesc Med 164: 328-333

61 Sanake N, Sato J, Tsushita $K$ et al. Prevention of type 2 diabetes in a primary healthcare setting: Three-year results of lifestyle intervention in Japanese subjects with impaired glucose tolerance. BMC Public Health 2011; 11: 40

62 Schulze MB, Fung TT, Manson JE et al. Dietary patterns and changes in body weight in women. Obesity (Silver Spring) 2006; 14: 1444-1453

63 Simonen RL, Perusse L, Rankinen T et al. Familial aggregation of physical activity levels in the Quebec Family Study. Med Sci Sports Exerc 2002; 34: 1137-1142

64 Sjöström L, Narbro K, Sjöström CD et al. Swedish Obese Subjects Study. Effects of bariatric surgery on mortality in Swedish obese subjects. N Engl J Med 2007; 23 (357): 741-752

65 Speakman JR, Rance KA, Johnstone AM. Polymorphisms of the FTO gene are associated with variation in energy intake, but not energy expenditure. Obesity (Silver Spring) 2008; 16: 1961-1965

66 Stampfer MJ, Hu FB, Manson JE et al. Primary prevention of coronary heart disease in women through diet and lifestyle. N Engl J Med 2000; 343: $16-22$

67 Stefan $N$, Thamer C, Staiger $H$ et al. Genetic variations in PPARD and PPARGC1A Determine Mitochondrial Function and Change in Aerobic Physical Fitness and Insulin Sensitivity during Lifestyle Intervention. J Clin Endocrinol Metab 2007; 92: 1827-1833

68 Stefanov TS, Vekova A, Kurktschiev D et al. Relationship of physical activity and eating behavior with obesity and type 2 diabetes mellitus: Sofia Lifestyle (SLS) study. Folia Medica 2011; 53: 11-18

69 Stubbe JH, Boomsma DI, Vink JM et al. Genetic influences on exercise participation in 37051 twin pairs from seven countries. PLoS One 2006; 1: e22

70 Stunkard AJ, Sorensen TI, Hanis C et al. An adoption study of human obesity. N Engl J Med 1986; 314: 193-198

71 Temelkova-Kurktschiev T, Hanefeld M, Chinetti G et al. Ala12Ala genotype of the peroxisome proliferator-activated receptor gamma2 protects against atherosclerosis. J Clin Endocrinol Metab 2004; 89: 4238-4242

72 Teran-Garcia M, Rankinen T, Bouchard C. Genes, exercise, growth, and the sedentary, obese child. J Appl Physiol 2008; 105: 988-1001

73 Thamer C, Machann J, Stefan $N$ et al. Variations in PPARD determine the change in body composition during lifestyle intervention: a whole-body magnetic resonance study. J Clin Endocrinol Metab 2008; 93: $1497-1500$

74 Timpson NJ, Emmett PM, Frayling TM et al. The fat mass- and obesityassociated locus and dietary intake in children. Am J Clin Nutr 2008; 88: 971-978

75 Tuomilehto J, Lindstrom J, Eriksson JG et al. Prevention of type 2 diabetes mellitus by changes in lifestyle among subjects with impaired glucose tolerance. N Engl J Med 2001; 344: 1343-1350

76 Uusitupa M, Peltonen M, Lindström J et al. For the Finnish Diabetes Prevention Study Group. Ten-year mortality and cardiovascular morbidity in the Finnish diabetes prevention study - secondary analysis of the randomized trial. PLOS ONE 2009; 4: e5656

77 van Dam RM, Rimm EB, Willett WC et al. Dietary patterns and risk for type 2 diabetes mellitus in U.S. men. Ann Intern Med 2002; 136: 201-209

78 Vaxillaire M, Froguel P. Genetic basis of maturity-onset diabetes of the young. Endocrinol Metab Clin North Am 2006; 35: 371-384 x

79 Vimaleswaran KS, Li S, Zhao JH et al. Physical activity attenuates the body mass index-increasing influence of genetic variation in the FTO gene. Am J Clin Nutr 2009; 90: 425-428

80 Vimaleswaran KS, Loos RJ. Progress in the genetics of common obesity and type 2 diabetes. Expert Rev Mol Med 2010; 12: e7

81 Wang J, Kuusisto J, Vanttinen $M$ et al. Variants of transcription factor 7-like 2 (TCF7L2) gene predict conversion to type 2 diabetes in the Finnish Diabetes Prevention Study and are associated with impaired glucose regulation and impaired insulin secretion. Diabetologia 2007; 50: $1192-1200$

82 Weyrich P, Machicao F, Reinhardt J et al. SIRT1 genetic variants associate with the metabolic response of Caucasians to a controlled lifestyle intervention - the TULIP Study. BMC Med Genet 2008; 9: 100

83 Wild S, Roglic G, Green A et al. Global prevalence of diabetes: estimates for the year 2000 and projections for 2030. Diabetes Care 2004; 27: 1047-1053

84 Wing RR, Venditti E, Jakicic JM et al. Lifestyle intervention in overweight individuals with a family history of diabetes. Diabetes Care 1998; 21: 350-359 